\begin{tabular}{lccc} 
VERSITA & GOSPODARKA & SUROWCAMI & MINERALNYMI \\
\hline \multirow{2}{*}{ Tom 28} & 2012 & Zeszyt 3 \\
& & DOI 10.2478/v10269-012-0023-1 &
\end{tabular}

\title{
Kamienie dekoracyjne i architektoniczne południowo-wschodniej Polski - złoża, zasoby i perspektywy eksploatacji
}

\section{Wprowadzenie}

Kamienie dekoracyjne i architektoniczne są najczęściej wydobywane w formie bloków, czyli brył skalnych o prostopadłościennych kształtach i wymiarach, zapewniających objętość odpowiednią dla mających powstać rzeźb, płyt okładzinowych czy elementów konstrukcji budowlanych. Wielkość bloków i ich zawartość w skalnej masie zależy od intensywności płaszczyzn podzielności i ich orientacji. Udział materiału blocznego w ocenianej objętości górotworu zwany jest blocznością geologiczną, zaś odniesiony do ilości wydobytego urobku - blocznością górniczą. W obu przypadkach wyrażany jest on w procentach i stanowi istotny parametr złóż surowców skalnych zaliczanych do kamieni blocznych i łamanych (dawniej drogowych i budowlanych), gdyż jest podstawą właściwego ich wykorzystania przy zastosowaniu odpowiednich metod eksploatacji. Ma to istotne znaczenie dla optymalizacji wydobycia, albowiem pozyskiwanie kamienia łamanego związane jest zwykle z intensywnym użyciem bryzantycznych materiałów wybuchowych, których stosowanie przyczynia się do powstawania nowych płaszczyzn podzielności i zaniku możliwości pozyskiwania bloków.

W Polsce południowo-wschodniej użytkowanie materiałów kamiennych od wczesnego średniowiecza wiąże się z rozwojem myśli technicznej, sztuki i architektury. Wielkość

* Dr hab. inż., prof. AGH, ** Dr inż., AGH Akademia Górniczo-Hutnicza, Wydział Geologii, Geofizyki i Ochrony Środowiska, Kraków; e-mail: bromow@geol.agh.edu.pl; figarska@agh.edu.pl 
wydobycia tych materiałów jest też odbiciem zmiennych warunków ekonomicznych regionu i całego kraju, czego przejawem są losy kopalń i zakładów obróbczych, zwanych dawniej fabrykami. Celem pracy jest ocena stanu przemysłu kamienia budowlanego nastawionego na produkcję materiałów architektonicznych i dekoracyjnych w Polsce południowo-wschodniej. Oparto ją na przeglądzie ponad 100 złóż, mniej lub bardziej związanych z jego wydobyciem, wybranych na podstawie bilansu zasobów (Bilans... 2010). Przedstawiono perspektywy oraz uzasadniono ekonomiczną opłacalność rozwoju wydobycia materiałów dekoracyjnych i architektonicznych w obrębie wybranych kopalin kamiennych z obszaru: Karpat, zapadliska przedkarpackiego, Roztocza, Gór Świętokrzyskich i ich mezozoicznego obrzeżenia oraz monokliny śląsko-krakowskiej.

\section{Historia i stan aktualny eksploatacji}

Na omawianym obszarze kamienie dekoracyjne i architektoniczne wydobywane są ze złóż piaskowców i skał węglanowych. Te ostatnie występują w złożach usytuowanych w obrębie trzonu paleozoicznego Gór Świętokrzyskich i ich mezozoicznego obrzeżenia, w obszarze monokliny śląsko-krakowskiej oraz w zapadlisku przedkarpackim i na Roztoczu. Piaskowce mogą być wydobywane ze złóż usytuowanych w obrębie mezozoicznego obrzeżenia Gór Świętokrzyskich oraz w Karpatach fliszowych.

\subsection{Skały węglanowe trzonu paleozoicznego i obrzeżenia mezozoicznego Gór Świętokrzyskich}

W regionie świętokrzyskim bloczne skały węglanowe związane są z osadami dewonu i permu w trzonie paleozoicznym Gór Świętokrzyskich oraz z osadami jury i kredy w jego mezozoicznym obrzeżeniu. Szczególnie interesujące są wśród nich gruboławicowe, silnie zlityfikowane wapienie o bogatej kolorystyce, posiadające zdolność przyjmowania poleru. Potocznie noszą one nazwę marmurów, a niekiedy też znane są pod nazwą marmurów technicznych.

Wśród dewońskich skał węglanowych szczególnie interesujące są grubo- i bardzo gruboławicowe wapienie o ciemnej kolorystyce $\mathrm{z}$ różnymi odcieniami. Ich dekoracyjność podkreśla obecność fauny reprezentowanej głównie przez amfipory i stromatopory, a także mniej lub bardziej liczne spękania zabliźnione białym lub zabarwionym na żółto i czerwono kalcytem (Peszat 1980). Oceniono kamieniołomy złóż: Bolechowice, Szewce (Góra Okraglica), Łagów i Skrzelczyce. Wśród skał permskich marmurami nazywane są zlepieńce złożone głównie z otoczaków skał węglanowych połączonych bogatym kalcytowym spoiwem. Ich najbardziej znaną odmianą są zlepieńce zygmuntowskie, występujące w złożu Zygmuntówka na Czerwonej Górze pod Kielcami. Historia wydobycia i obróbki omawianych kamieni, określanych nieraz wspólną nazwą wapieni chęcińskich, sięga XVI wieku, kiedy to podskarbi Jan Firlej w liście do króla z 1599 r. podawał, że w Chęcinach wykonywana jest 
posadzka bez polerowania, którą prosto odbijana posyłaja (Łopaciński 1902). Nie można pominąc informacji o wcześniejszych przykładach wykorzystania omawianych marmurów jako tablic inskrypcyjnych z datami 1553 i 1569, o których wspominają Z. Guldon i W. Kowalski (1984). Później informacje o wydobyciu marmurów w okolicy Chęcin i ich wykorzystaniu podawane są w wielu publikacjach, sprawozdaniach z lustracji dóbr królewskich i zachowanych rękopisach, zestawionych w pracach H. Łopacińskiego (1902) i E. Weber-Kozińskiej (1961). Wynika z nich, że okresy rozkwitu i zaniku kamieniarskiego rzemiosła, a potem przemysłu są nierozerwalnie związane z losami Rzeczypospolitej.

Spośród ocenianych w terenie wystąpień marmurów paleozoicznych na specjalną uwagę zasługują kamieniołomy usytuowane w obrębie złóż Bolechowice i Zygmuntówka (Bromowicz, Figarska-Warchoł 2011b). W pierwszym z nich, znanym pod nazwą Panek i uważanym za najstarsze, ciągle czynne wyrobisko kieleckich marmurów, produkowane jest kruszywo, w drugim zaś zaniechano eksploatacji. Barwa skały w Bolechowicach, często brązowa z różowym odcieniem, odbiega od dominującej zwykle wśród wapieni dewońskich szarobrązowej. Fauna, złożona głównie ze stromatoporoidów o zróżnicowanej wielkości, małży, koralowców, szkarłupni i ślimaków wraz z ciekawą barwą skały powoduje duże optyczne urozmaicenie polerowanych powierzchni. W złożu Zygmuntówka unikalność zlepieńca wynika ze sposobu wykształcenia spoiwa i składu materiału okruchowego. Spoiwo typu matrix ma czerwoną barwę, której towarzyszy biała - związana z silnie rozwiniętymi żyłami kalcytu pochodzenia hydrotermalnego (Zbroja i in. 1998). Skład materiału okruchowego jest dosyć jednorodny. Tworzą go głównie różnie obtoczone otoczaki wapieni dewońskich z niewielką ilością dolomitów (Kostecka 1966). Rozwinięty lokalnie wysoki stopień lityfikacji, być może związany ze wspomnianą działalnością roztworów hydrotermalnych, sprawia, że skała przyjmuje poler i utrzymuje go izolowana od wpływów warunków atmosferycznych. Orientacja płaszczyzn podzielności w obu kamieniołomach daje układ prawie ortogonalny, a odległości między nimi sprawiają, że oceniony dla kamieniołomu Panek wskaźnik bloczności geologicznej (44\%) był najwyższy spośród badanych złóż wapieni dewońskich, a dla Zygmuntówki - najwyższy spośród wszystkich badanych złóż skał osadowych w Polsce i wynosił ponad 60\% (Bromowicz, Figarska-Warchoł 2011b).

Wapienie jurajskie omawianego obszaru wykorzystywane jako materiały dekoracyjne związane są z dwoma kompleksami - starszym oksfordzkim, znanym pod nazwą tuberolitowych wapieni morawickich i młodszym, kimerydzkim wapieni oolitowych. W pierwszym wapienie są grubouławicone, pelityczne z liczną fauną głowonogów i ramienionogów oraz silnym rozwojem szwów stylolitowych. Ich barwa jest jasno- lub żółtawoszara o charakterystycznych ciemniejszych od tła plamkach. Wapienie te są pozyskiwane w kamieniołomach złóż Wola Morawicka i Morawica III. Wśród młodszych wapieni jurajskich zainteresowanie budzą wapienie oolitowe. Sa grubo-, rzadziej średnio- i cienkoławicowe o barwach białej i żółtawej. Na wygładzonych powierzchniach widoczne są ooidy, okruchy wapieni oraz pokruszone szczątki organiczne. Wapienie te występują w wielu odsłonięciach południowo-zachodniej części obrzeżenia Gór Świętokrzyskich (Peszat 1964) i były eksploatowane w formie bloków ze złoża Goluchów w pobliżu Pińczowa. 
Kredowe skały węglanowe wykorzystywane w budownictwie i jako materiał rzeźbiarski są najbardziej znane z okolic Ożarowa. Są to skały silnie porowate, białe lub żółtawe, znane jako opoki. Bloki tych skał wydobywane były od lat siedemdziesiątych XVI w. ze złoża Janików, a od lat pięćdziesiątych ubiegłego wieku ze złoża Karsy (Wardzyński 2004). Aktualnie w obu zaniechano wydobycia.

\subsection{Skały węglanowe monokliny śląsko-krakowskiej}

Na monoklinie śląsko-krakowskiej dekoracyjne i architektoniczne węglanowe materiały kamienne związane są z utworami dewonu, karbonu, triasu i jury. Wśród dwóch pierwszych występują marmury techniczne. W pozostałych lokalnie tylko stopień lityfikacji skał daje możliwość uzyskania faktury polerowanej. Aktualnie nigdzie nie prowadzi się eksploatacji wapieni karbońskich z przeznaczeniem na bloki, mimo iż w przeszłości wydobywano je pod nazwą marmury racławickie. Wykorzystywane w tym samym celu wapienie dewońskie w okolicy Krzeszowic znane są pod nazwą marmurów dębnickich. Obok czarnej barwy i zdolności przyjmowania poleru posiadają białe użylenie i zawierają szczątki organiczne oraz struktury i tekstury nadające urozmaicony wygląd ich wypolerowanej powierzchni. Niekiedy na kontakcie z występującymi w podłożu porfirami pojawiają się ich zmienione odmiany. Dzięki pracy W. Tatarkiewicza (1952) wiadomo, że najstarsze, wiarygodne wiadomości dotyczące wydobycia wapieni (1643) wiążą się z rodziną Firlejów, tak jak w przypadku wapieni chęcińskich. Ponad czterystuletnia tradycja stosowania marmurów dębnickich w architekturze sprawia, że mimo niewielkiej miąższości ich kompleksu (ok. 35 m), w obrębie wychodni o powierzchni zaledwie 48 ha znajduje się kilkanaście kamieniołomów różnej wielkości. Największe z nich są związane ze złożami Dębnik i Dębnik I. Silne zaangażowanie tektoniczne oraz zjawiska kontaktowe są przyczyną ich małej bloczności. Jest to jednakże jedyne miejsce w naszym kraju, gdzie istnieją możliwości pozyskiwania bloków czarnych, polerujących się wapieni (Bromowicz 2001).

Dolomity diploporowe wykorzystywane jako materiały dekoracyjne i architektoniczne występują wśród osadów środkowego triasu monokliny śląsko-krakowskiej. Jest to zespół o miąższościach ławic najczęściej około $1 \mathrm{~m}$, tworzący maksymalnie 50-metrowy kompleks skalny. Dolomity są drobnodetrytyczne o dość jednorodnej kolorystyce jasnoszarożółtej, a jedynie w części przypowierzchniowej bardziej rdzawej. Składniki okruchowe skały, opisane przez Myszkowską (1992) są urozmaicone. Do walorów dekoracyjnych tego materiału, oprócz barwy i skamieniałości, należy też obecność wypełnionych węglanami kawern. Dolomity te rozpoznano w murach kruchty krakowskiego kościoła św. Katarzyny wzniesionej w latach 1420-1430 (Dobrowolski 1964), a także romańskiego kościoła w Kuźnicy Świętojarskiej (Tołkanowicz 2002). Kamieniołom, w którym pozyskiwano bloki dolomitu diploporowego należy do złoża Libiaż̇. Jest to duże, wgłębne wyrobisko, produkujące głównie kruszywo z dolomitów kruszconośnych.

Wapienie jurajskie monokliny śląsko-krakowskiej budują pasmo, znane pod nazwą Jury Krakowsko-Wieluńskiej. Generalnie zapadają one monoklinalnie ku NE i poprzecinane są 
wieloma uskokami, tworzącymi tektoniczne zręby i rowy. Wykorzystywane były w budownictwie od wczesnego średniowiecza. Najczęstsze, spośród wyróżnianych wśród nich odmian, były wapienie uławicone o miąższości do $2 \mathrm{~m}$ i zwykle ortogonalnym układzie płaszczyzn spękań. Na świeżym przełamie są one jasnobrązowe, a po zwietrzeniu białe, zwykle detrytyczne z licznymi bio- i intraklastami, a także krzemieniami. Ich wykształcenie oceniono w kamieniołomach położonych w północnej części pasma Jury Krakowsko-Wieluńskiej w okolicy Działoszyna oraz w wyrobiskach najbardziej południowej jego części w okolicach Krakowa, w złożach: Nielepice, Kamień-Odwozy, Mirów-Kamir i Ulina Wielka.

W usytuowanych na S i SW od Działoszyna, złożach Zalesiaki, Raciszyn i Raciszyn II występuje szczególna odmiana wapieni jurajskich nazwana przez A. Wierzbowskiego (1978) skalistym wapieniem zalesiackim. Są to gruboławicowe wapienie o jasnych barwach żółtobrązowych, silnie zlityfikowane i przyjmujące poler, zawierające zwykle kierunkowo ułożone makropory. Ich obecność powoduje, że wapień, wśród kamieniarzy, jest błędnie określany mianem polskiego trawertynu (Smoleńska 1983). Wapienie te eksploatowane od połowy ubiegłego stulecia, przez szereg lat znajdowały się w gestii PKP i stąd ich zastosowanie $\mathrm{w}$ formie polerowanych płyt obserwować można we wnętrzach budynków stacji kolejowych m.in. w Krakowie i Wrocławiu. Bardzo korzystny wskaźnik bloczności, oceniony dla kamieniołomu na ponad $40 \%$, a dla całego złoża około $20 \%$ stwierdzono w złożu Raciszyn.

W profilach pozostałych kamieniołomów, powyżej wymienionych złóż w południowej części Jury Krakowsko-Częstochowskiej, obok wapieni uławiconych pojawiają się zwykle nie rokujące możliwości pozyskiwania bloków wapienie skaliste i płytowe. Pierwsze, masywne, mają nieregularny układ płaszczyzn podzielności, drugie zaś słabiej zlityfikowane, rzadko są gruboławicowe i stąd przy wydobyciu dają bryły kształtem zbliżone do płyt.

\subsection{Wapienie zapadliska przedkarpackiego i Roztocza}

W zapadlisku przedkarpackim i na Roztoczu materiały kamienne wykorzystywane jako dekoracyjne i architektoniczne to trzeciorzędowe wapienie organodetrytyczne o zmiennym uziarnieniu, w przewadze grubodetrytyczne. Sąjasnożółtawe, z czasem zmieniając barwę na szarobrązową i żółtoszarą. Należą do wapieni lekkich - mają zmienną zwięzłość i dużą porowatość wynikającą z niskiego stopnia lityfikacji. Duża porowatość daje możliwość zastosowania ich do budowy murów pomieszczeń mieszkalnych w naszych warunkach klimatycznych (Lyczewska 1975; Musiał 1987). Wapienie te łatwo poddają się obróbce i stąd jako jedna z niewielu skał nadają się do rzeźbienia bardzo delikatnych detali o przestrzennej formie. Od wczesnego średniowiecza wykorzystywane były jako materiał budowlany i rzeźbiarski (Weber-Kozińska 1961).W zapadlisku przedkarpackim wapienie te, znane jako pińczowskie, pozyskiwane są ze złóż Pińczów i Włochy, na Roztoczu zaś - Brusno, Babia Dolina i Józefów. W formie bloków i kształtek budowlanych są one wydobywane w złożach o jednolitych, gruboławicowych seriach złożowych, zawierających wapienie o zbliżonym 
stopniu lityfikacji (Józefów, Pińczów i Włochy). W pozostałych, gdzie występuje zróżnicowane uławicenie (Brusno) czy zmienny stopień lityfikacji (Babia Dolina) bloki wapienne towarzyszą jedynie pozyskiwaniu kruszyw.

\subsection{Piaskowce obrzeżenia mezozoicznego \\ Gór Świętokrzyskich}

W obrzeżeniu Gór Świętokrzyskich występują kompleksy piaskowców wieku triasowego, jurajskiego i kredowego o dużych tradycjach stosowania w architekturze. Ich wychodnie ukazują się w kolejności stratygraficznej od trzonu paleozoicznego, głównie w kierunku północnym. Mimo różnego wieku mają zbliżone cechy litologiczne: są kwarcowymi arenitami o ubogim spoiwie krzemionkowo-ilastym i o słabo zaznaczonym procesie lityfikacji. Powoduje to ich znaczną porowatość i nasiąkliwość, z których pierwsza przekracza niekiedy $20 \%$, druga zaś osiąga 10\%. Generalnie, właściwości ich są lepsze w starszych utworach geologicznych (Peszat 1973).

Piaskowce triasowe rozwinięte są pomiędzy Opatowem na wschodzie i Radoszycami na zachodzie. Pozyskiwanie z nich kamieni dekoracyjnych i architektonicznych wiązać można z osadami dolnego triasu oraz najwyższej części triasu górnego zwanego retykiem. Zasadniczo piaskowce dolnotriasowe są barwy czerwonej i wiśniowej, podczas gdy górnotriasowe - szarożółtawej ze smugami o zabarwieniu ciemnożółtawym. Reprezentują one różne typy technologiczne i znane są pod różnymi nazwami. Z dolnotriasowych w złożu Kopaniny pozyskiwane są piaskowce gałęzickie, w złożach Tumlin-Gród i Sosnowica - tumlińskie, Kopulak i Zajaczków - wachockie, a w Parszowie - piaskowce retyckie z warstw parszowskich. Piaskowce gatęzickie, użytkowane już od XIV wieku, są bloczne, szarowiśniowe, średnioziarniste z pojedynczymi ziarnami kwarcowymi frakcji żwirowej. Piaskowce tumlińskie o nieco jaśniejszych barwach dzielą się wzdłuż płaszczyzn przekątnej laminacji dając głównie płaskie kształtki i jedynie sporadycznie bloki. Znacznie bardziej korzystne jest pozyskiwanie bloków w złożu Kopulak, gdzie bloczność oceniono na ponad 40\% (dla kamieniołomu ponad 70\%). Miąższość ławic piaskowców o raczej wiśniowym zabarwieniu sięga tam 4 m, pojawia się w nich frakcja żwirowa i toczeńce łupkowe, a także obniżające jakość materiału, łatwo wymywane przez wodę, nagromadzenia hematytowe. Nie ma ich w piaskowcach wachockich złoża Zajaczków. Piaskowce te z wychodni w Wąchocku zostały wykorzystane przez cystersów do wzniesienia romańskiego kościoła i klasztoru (Rubinowski i in. 1986). W złożu Parszów serię złożową stanowią piaskowce średnioziarniste i równoziarniste $\mathrm{w}$ ławicach o ponad metrowej miąższości. Połogie zaleganie warstw przy pionowym przebiegu spękań ciosowych sprzyja pozyskiwaniu bloków (Bromowicz, Figarska-Warchoł 2011a).

Wydobycie piaskowców jurajskich prowadzone jest w kamieniołomach dolnoliasowej serii ostrowieckiej, środkowoliasowej - drzewickiej i górnoliasowej - borucickiej. W serii ostrowieckiej eksploatacja piaskowców prowadzona jest w okolicach Żarnowa (tzw. $\dot{z} a r-$ nowskie). Zapewne posłużyły one do wzniesienia romańskiej świątyni w tej miejscowości 
(Lechowicz 2010). Są tu czynne złoża Żarnów, Sielec oraz Tresta Wesoła. W okolicy Opoczna znajdują się złoża Mroczków Gościnny i Kraszków. W pobliżu Szydłowca bloki piaskowcowe tej serii pozyskiwane są w kamieniołomach złóż zgrupowanych w rejonie Broniowa. Były też wydobywane w Wąchocku. Piaskowce są drobno- i bardzo drobnoziarniste o barwie żółtej z przemazami brązowymi, a niekiedy i różowymi (Kobylec 2008). Ich gruboławicowe serie złożowe mają dużą bloczność, a ogranicza ją pojawiająca się w płytkich wyrobiskach podzielność pokładowa, pozwalająca na uzyskanie jedynie płytkowych kształtek zwanych tupankq lub dzikówkq. Piaskowce serii drzewickiej eksploatowane były od XV wieku w okolicy Szydłowca oraz Kunowa (Urban, Gagol 1994). Obecnie wydobywane są jedynie piaskowce szydlowieckie w ponad dwudziestu, przeważnie niewielkich złożach. Są drobno- i równoziarniste, gruboławicowe, o miąższościach sięgających $4 \mathrm{~m}$ i barwach białych, niekiedy tylko lekko żółtawych. Ich bloczność oceniona w złożu Śmitów 1 sięga $60 \%$. Piaskowce serii borucickiej są eksploatowane na zachód od Żarnowa w kamieniołomach Wolica i Dabie II. Są to piaskowce bardzo drobnoziarniste, niezbyt zwięzłe, gruboławicowe, o delikatnej laminacji i atrakcyjnych barwach żółtobrązowych $\mathrm{z}$ różowymi smugami.

Piaskowce kredowe z Góry Chełmo, położonej na zachód od Przedborza wykorzystywane sąjako materiał budowlany już od X w. (Krystek 2005). Kamieniołomy usytuowane są na południowych jej stokach i ukazują bardzo grube (o miąższości do $10 \mathrm{~m}$ ) ławice piaskowców o barwie od lekko żółtawej do brązowej z żelazistymi naciekami. Są one średnio- i nierównoziarniste z ziarnami do $3 \mathrm{~mm}$. Uławicenie i ortogonalny układ rzadkich płaszczyzn ciosowych zapewniają duże możliwości pozyskania bloków.

\subsection{Piaskowce karpackie}

Piaskowce karpackie z racji głębokomorskiej, fliszowej sedymentacji i procesów diagenetycznych, wzmaganych grubym nadkładem i tektonicznymi zaburzeniami, zdecydowanie różnią się od powyżej omówionych. Ich barwy są zawsze szare z odcieniami niebieskimi, zielonymi lub żółtymi. Posiadają zwykle urozmaicony skład mineralny materiału okruchowego i spoiwa. Zawsze współwystępują z łupkami, mają silnie zróżnicowane miąższości ławic i charakterystyczne struktury typu laminacji lub też warstwowania frakcjonalnego. Sposób wykształcenia serii fliszowych, jak też ich silne zaangażowanie tektoniczne nie sprzyjają uzyskiwaniu bloków. Spośród wyróżnianych we fliszu karpackim ogniw litostratygraficznych tylko nieliczne posiadają znaczenie surowcowe. Możliwości pozyskiwania bloków dają piaskowce godulskie, istebniańskie i krośnieńskie z płaszczowiny śląskiej oraz magurskie z płaszczowiny magurskiej.

Piaskowce godulskie w sposób najbardziej typowy rozwinięte są w Beskidzie Śląskim. Pozyskiwanie materiałów budowlanych związane jest ze środkowym poziomem warstw godulskich, w którym przeważają gruboławicowe piaskowce średnio- i drobnoziarniste o barwach zielonkawo- i niebieskawoszarych z bardzo rzadkimi i cienkimi wkładkami łupkowymi (Kamieński i in. 1968). Najważniejsze złoża blocznych piaskowców godulskich 
są usytuowane w miejscowości Brenna, na południowy wschód od Skoczowa. Należą do nich: Cisowa, Cisowa I, Gtębiec, Brenna M, Beskid, Tokarzówka i Tokarzówka I.

Piaskowce istebniańskie są silnie rozwinięte w Beskidzie Śląskim i Małym. Budują też Pogórze Lanckorońskie, Wielickie, Wiśnickie i Rożnowskie. Dalej na wschód znane są z pasma Brzanki - Liwocza, a także z okolic Frysztaku - Węglówki i Baligrodu (Peszat i in. 1976). Od wczesnego średniowiecza należą do najpopularniejszych materiałów budowlanych południowej Polski. Są przeważnie grubo- i nierównoziarniste, miejscami zlepieńcowate $\mathrm{w}$ grubych ławicach sięgających nawet $5 \mathrm{~m}$. Z reguły są bezwapniste, o ubogim spoiwie ilastym z domieszką krzemionkowego. Barwy mają jasnoszare i żółtawe, rdzawobrązowe, jak też brunatne. Ich ostatnio czynne złoża zgrupowane są w okolicach DobczycCzasław, Bochni - Sobolów oraz Krosna - Wola Komborska. Największe możliwości produkcji i uzysku bloków oceniono dla złoża Sobolów, gdzie bloczność przekracza 40\%.

Piaskowce magurskie występują na dużym obszarze płaszczowiny magurskiej, gdzie zwykle budują grzbiety górskie. Jako materiał dekoracyjny i architektoniczny są eksploatowane w kamieniołomach Tenczyn-Lubień, Tenczyn-Lubień I i Tenczyn-Lubień II w Beskidzie Makowskim, Męcina I i Walowa Góra w Beskidzie Wyspowym oraz Barcice w Beskidzie Sądeckim. We wszystkich tych miejscach eksploatowane są piaskowce gruboławicowe, średnioziarniste, często z pojedynczymi ziarnami frakcji żwirowej, o przeważającej barwie szaroniebieskiej zmieniającej się na żółtobrązową po zwietrzeniu.

Piaskowce krośnieńskie najkorzystniej rozwinięte są w dolnej części profilu, gdzie koncentrują się ich gruboławicowe odmiany rokujące możliwości uzysku bloków. Są one średnioziarniste z większymi ziarnami do $5 \mathrm{~mm}$. Charakterystyczne dla nich są niebieskie odcienie szarej barwy na świeżym przełamie i wietrzenie na brązowo, a także liczne występowanie stosunkowo dużych blaszek muskowitu oraz obecność dolomitu wśród węglanowego spoiwa (Moroz-Kopczyńska 1977). Ich bloki wydobywane są na większą skalę jedynie w kamieniołomach Barwałd i Górka-Mucharz w okolicy Wadowic. Szczególnie atrakcyjne jest to ostatnie złoże z połogim zaleganiem kilku bardzo grubych ławic piaskowcowych o dosyć regularnym układzie płaszczyzn podzielności ze wskaźnikiem bloczności $31 \%$ dla kamieniołomu i $22 \%$ dla całego złoża.

\section{Perspektywy rozwoju eksploatacji}

Wobec pojawienia się zapotrzebowania na kruszywa i małego zainteresowania rodzimymi kamiennymi materiałami dekoracyjnymi, praktycznie zaniechano pozyskiwania bloków ze skał, których właściwości fizyczno-mechaniczne zapewniają możliwości zbytu wykonanego z nich kruszywa. Na większą skalę bloki pozyskiwane są jedynie ze skał porowatych o małej wytrzymałości na ściskanie i znacznej nasiąkliwości. W ostatnich latach znacznie wzrosła liczba eksploatowanych złóż tego typu skał. Wynika stąd, że pozyskiwanie bloków jest czynnością intratną, chociaż przynoszącą mniejsze zyski niż produkcja kruszywa. Zarysowany powyżej potencjał produkcji materiałów kamiennych wykorzystywanych 
jako elementy dekoracyjne i architektoniczne w Polsce południowo-wschodniej został wobec tego zmniejszony na skutek zmian wywołanych prawami wolnego rynku.

Baza zasobowa aktualnie produkowanych kamieni dekoracyjnych i architektonicznych jest znaczna i zabezpieczona w złożach o rozpoznanych zasobach, lecz nieeksploatowanych (tab. 1). Szczególnie dynamicznie rozwija się wydobycie w obrębie złóż piaskow-

TABELA 1

Złoża kamieni blocznych w SE Polsce

The deposits of dimension stones in SE Poland.

\begin{tabular}{|c|c|c|c|c|c|c|c|c|c|}
\hline & \multicolumn{3}{|c|}{ Złoża eksploatowane } & \multicolumn{3}{|c|}{ Złoża zaniechane } & \multicolumn{3}{|c|}{ Złoża rozpoznane } \\
\hline & $\begin{array}{c}\text { liczba } \\
\text { złóż }\end{array}$ & $\begin{array}{c}\text { zasoby } \\
\text { bilans. } \\
{\left[10^{6} \mathrm{Mg}\right]}\end{array}$ & $\begin{array}{c}\text { powierz- } \\
\text { chnia } \\
\text { [ha] }\end{array}$ & $\begin{array}{l}\text { liczba } \\
\text { złóż }\end{array}$ & $\begin{array}{c}\text { zasoby } \\
\text { bilans. } \\
{\left[10^{6} \mathrm{Mg}\right]}\end{array}$ & $\begin{array}{c}\text { powierz- } \\
\text { chnia } \\
\text { [ha] }\end{array}$ & $\begin{array}{c}\text { liczba } \\
\text { złóż }\end{array}$ & $\begin{array}{c}\text { zasoby } \\
\text { bilans. }\left[10^{6}\right. \\
\mathrm{Mg}]\end{array}$ & $\begin{array}{c}\text { powierz- } \\
\text { chnia } \\
\text { [ha] }\end{array}$ \\
\hline Marmury techniczne & 7 & 167431 & 276,3 & 8 & 35584 & 62,0 & 14 & 172131 & 228,8 \\
\hline Wapienie dewońskie & 3 & 25716 & 35,7 & 6 & 26226 & 46,4 & 9 & 137302 & 169,9 \\
\hline Wapienie karbońskie & 0 & 0 & 0,0 & 0 & 0 & 0,0 & 1 & 6425 & 4,1 \\
\hline Wapienie permskie & 0 & 0 & 0,0 & 1 & 4936 & 7,3 & 1 & 17164 & 25,2 \\
\hline Wapienie jurajskie & 4 & 141715 & 240,6 & 1 & 4422 & 8,3 & 3 & 11240 & 29,6 \\
\hline Wapienie i dolomity & 8 & 120309 & 203,4 & 5 & 24989 & 141,3 & 17 & 411932 & 1167,5 \\
\hline Dolomity triasowe & 4 & 106529 & 168,8 & 1 & 2273 & 4,5 & 9 & 264005 & 1035,9 \\
\hline Wapienie jurajskie & 4 & 13780 & 34,6 & 4 & 22716 & 136,8 & 8 & 147927 & 131,6 \\
\hline Wapienie lekkie & 5 & 9578 & 37,3 & 11 & 44426 & 194,2 & 3 & 2686 & 14,1 \\
\hline Wapienie organodetrytyczne & 5 & 9578 & 37,3 & 10 & 25979 & 148,2 & 3 & 2686 & 14,1 \\
\hline Opoka & 0 & 0 & 0,0 & 1 & 18447 & 46,0 & 0 & 0 & 0,0 \\
\hline Piaskowce platformowe & 56 & 12510 & 64,3 & 11 & 15702 & 66,0 & 27 & 85133 & 151,6 \\
\hline Piaskowce triasowe & 6 & 1641 & 8,5 & 3 & 1820 & 8,7 & 2 & 2233 & 16,6 \\
\hline Piaskowce jurajskie & 46 & 8499 & 49,4 & 8 & 13882 & 57,3 & 21 & 74487 & 115,4 \\
\hline Piaskowce kredowe & 4 & 2370 & 6,4 & 0 & 0 & 0,0 & 4 & 8413 & 19,6 \\
\hline Piaskowce karpackie & 28 & 125902 & 129,3 & 9 & 23705 & 21,1 & 25 & 436021 & 362,5 \\
\hline Piaskowce godulskie & 9 & 14389 & 13,6 & 1 & 500 & 0,5 & 3 & 54195 & 36,5 \\
\hline Piaskowce istebniańskie & 6 & 1884 & 8,5 & 4 & 3988 & 5,1 & 2 & 748 & 1,8 \\
\hline Piaskowce krośnieńskie & 4 & 43748 & 40,4 & 1 & 5918 & 4,3 & 12 & 221859 & 182,6 \\
\hline Piaskowce magurskie & 9 & 65881 & 66,8 & 3 & 13299 & 11,2 & 8 & 159219 & 141,6 \\
\hline Razem & 104 & 435730 & 710,6 & 44 & 144406 & 484,6 & 86 & 1107903 & 1924,5 \\
\hline
\end{tabular}



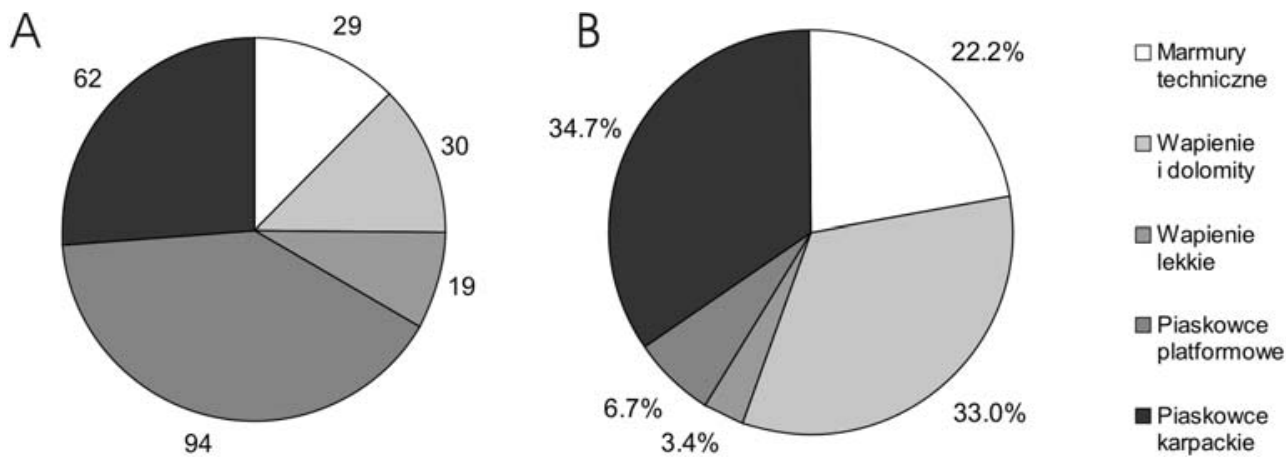

Rys. 1. Liczba złóż kamieni dekoracyjnych i architektonicznych w Polsce SE (A) i udział ich zasobów (B)

Fig. 1. The number of deposits of decorative and architectural stones in SE Poland (A) and their percentage in total resources $(\mathrm{B})$

ców z obrzeżenia Gór Świętokrzyskich (platformowych), gdzie zarejestrowano 94 złoża, z których 56 jest czynne (rys. 1).

Mniejsze jest zainteresowanie blokami z wapieni lekkich. Są one pozyskiwane zaledwie w pięciu złożach, wyłącznie wapieni detrytycznych. Natomiast nigdzie nie są wydobywane opoki. Ewentualne zwiększone zapotrzebowanie na bloki wapieni lekkich z łatwością może być zaspokojone poprzez wznowienie eksploatacji jedenastu, dawniej czynnych, a obecnie zaniechanych złóż (tab. 1).

Możliwość powrotu do wydobycia bloków ze skał aktualnie wykorzystywanych jako kruszywa wiąże się z koniecznością pojawienia się popytu na wyroby, których produkcja będzie przynosić zyski przewyższające dochody z produkcji kruszyw. Zapewniają je złoża o dużych zasobach materiału blocznego, tj.: zlepieńce zygmuntowskie, przyjmujące poler wapienie jurajskie oraz posiadające ciepłe, żółtawobrązowe barwy dolomity diploporowe.

Pozostałe skały węglanowe (dewońskie i karbońskie) zaliczane do marmurów technicznych są eksploatowane w trzech złożach, w sześciu zaniechano ich wydobycia, a rozpoznane zostały w dziesięciu kolejnych. Ich łączne zasoby bilansowe przekraczają $195 \mathrm{mln} \mathrm{Mg}$, stanowiąc 11,6\% wszystkich zasobów złóż blocznych opisywanego obszaru, a 5,9\% zasobów złóż eksploatowanych (tab. 1). Przyjmując w uproszczeniu małą (10\%) bloczność wszystkich tych złóż, ich udokumentowane zasoby powinny obejmować nie mniej niż 19,5 mln Mg bloków, co przy dodatkowym założeniu bardzo wysokiego rocznego wydobycia rzędu 80 tys. Mg powinno zapewnić możliwości eksploatacji na ponad 240 lat. Jeśli ponadto uwzględni się zasoby prognostyczne ocenione jedynie dla wapieni dewońskich w Górach Świętokrzyskich (ponad $740 \mathrm{mln} \mathrm{Mg}$ ), to wydaje się, że istnieją ogromne możliwości w zakresie wydobycia bloków paleozoicznych marmurów technicznych. Znacznie przeważają we wszystkich stopniach rozpoznania i udostępnienia złoża położone w Górach Świętokrzyskich, głównie w powiecie kieleckim, przy znacznie mniejszym udziale złóż z powiatu opatowskiego. Pojedyncze złoża wapieni dewońskich i karbońskich z monokliny śląsko-krakowskiej usytuowane są w powiecie krakowskim (rys. 2). 


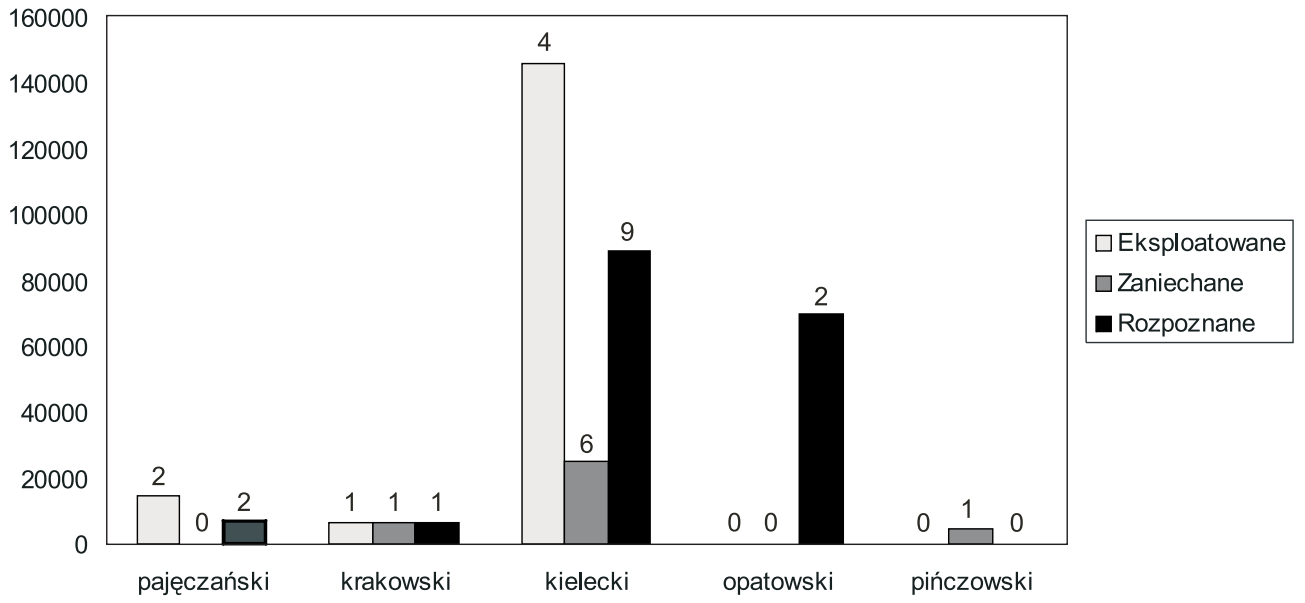

Rys. 2. Eksploatowane, zaniechane i rozpoznane złoża marmurów technicznych w powiatach SE Polski: ich zasoby [tys. Mg] i liczba (numery na wykresie)

Fig. 2. Exploited, closed and documented deposits of technical marbles in districts of SE Poland: their resources [thousands of $\mathrm{Mg}$ ] and number (numbers on the figure)

Perspektywy rozwoju wydobycia kamieni dekoracyjnych i architektonicznych są zróżnicowane w zależności od cech poszczególnych skał, ich bloczności i wielkości zasobów. Mając powyższe na uwadze, znaczenie omawianych złóż może mieć wymiar europejski, krajowy i lokalny. Do pierwszej grupy należy zaliczyć permskie zlepieńce zygmuntowskie, triasowe dolomity diploporowe oraz jurajskie wapienie zalesiackie i morawickie.

Zlepieńce zygmuntowskie, mimo iż w najbardziej atrakcyjnej formie występują w jednym tylko złożu, z racji powyżej opisanych walorów mogą stanowić konkurencję na europejskim rynku kamieniarskim. Tego rodzaju skały oferowane w Austrii (pod nazwami: Lindabrunn, Ternitz, Untersberg) i Niemczech (Brannenburg) wydają się być znacznie mniej atrakcyjne z racji mało wyrazistych, szarych i żółtych, co najwyżej lekko różowawych barw. Zasoby bilansowe złoża Zygmuntówka sięgające prawie $5 \mathrm{mln} \mathrm{Mg} \mathrm{mogą} \mathrm{dawać} \mathrm{po}$ około $1500 \mathrm{~m}^{3}$ bloków w ciągu kolejnych 500 lat, przy założeniu rocznego wydobycia rzędu 10 tys. Mg i bloczności na ostrożnym poziomie 40\%. Położenie na terenie Chęcińsko-Kieleckiego Parku Krajobrazowego nie powinno stanowić ograniczenia dla eksploatacji złoża, której celem będzie produkcja bloków. Powrót do kamieniarskiej tradycji, nawiązującej do historycznego wykorzystania wydobytego tutaj bloku na warszawską kolumnę Zygmunta III Wazy (XVII w.), może być źródłem geoturystycznego zainteresowania obiektem.

Pozyskiwanie bloków dolomitów diploporowych jest możliwe w czternastu złożach (tab. 1). Bloki tego materiału wydobywane są jedynie w powyżej wspomnianym złożu Libiaż, z najwyższego poziomu, w którym oceniona przed laty bloczność wynosiła około $10 \%$. Przy ocenie perspektyw rozwinięcia na większą skalę pozyskiwania bloków dolomitów diploporowych konieczna jest weryfikacja informacji zawartych $w$ istniejących dokumen- 
tacjach pod kątem wydzielenia obszarów rokujących największe możliwości uzysku bloków. Wyróżnienie takich obszarów ułatwiają duże powierzchnie dokumentowanych złóż oraz połogie zaleganie warstw. Na szczególną uwagę zasługują zwarte kompleksy skał węglanowych triasu, gdyż złoża położone w zasięgu południowych wychodni, w wyniesionych blokach tektonicznych są zapewne silniej spękane. Godne uwagi są złoża: Niesułowice-Lgota w gminie Olkusz, a także Byczyna w gminie Jaworzno. Trzeba też rozpatrzyć podobne możliwości w złożu Chruszczobród (gmina Łazy) o ogromnej powierzchni 147 ha, w którym miąższość dolomitów, stwierdzona w 80 otworach wiertniczych, sięga średnio $30 \mathrm{~m}$. Podobne do omawianych, żółte dolomity pochodzą na rynku kamieniarskim z Bawarii w Niemczech ( np. Goldberg), z Andaluzji w Hiszpanii (Amarillo) i z Estonii (np. Dolomite Orgita).

Korzystne warunki do zwiększenia wydobycia wapieni zalesiackich jako materiałów dekoracyjnych i architektonicznych istnieją w złożach Zalesiaki, Raciszyn i Raciszyn II. Ponad 10-hektarowe powierzchnie złóż, przy prawie poziomym zaleganiu serii złożowej, sięgającej 25 m miąższości, o znacznej bloczności i niskim stopniu rozdrobnienia materiału blocznego, zapewniają możliwości dużej produkcji, mimo ograniczonego występowania ich wychodni. Największy potencjał ma złoże Raciszyn, mniejszy Zalesiaki z uwagi na prowadzoną tam eksploatację kruszywa, a także złoże Raciszyn II, gdzie w serii złożowej zaznacza się, stwierdzony przez A. Smoleńską (1983), większy udział słabiej zlityfikowanych wapieni. Podobne, kawerniste wapienie o brązowozłocistych barwach są - poza trawertynami reprezentowane jedynie przez portugalski wapien Santo Antonio z krainy Estremadura.

Tuberolitowe wapienie morawickie zwane też plamkowymi również posiadają cechy zapewniające rozwój eksploatacji na dużą skalę i stworzenie konkurencji dla materiałów proponowanych na rynku europejskim. Wynika to z ich korzystnych walorów dekoracyjnych, dużych możliwości wydobywania bloków i niewielkiego stopnia rozdrobnienia materiału blocznego. Szczególnie korzystnie są rozwinięte w złożu Wola Morawicka, w którym bloczność należy do najwyższych wśród marmurów technicznych w Polsce (Bromowicz, Figarska-Warchoł 2011b). Intensywny rozwój zagospodarowania złoża może zapewnić powrót do masowej eksploatacji, zapewniającej duże wydobycie bloków. Obecnie jednak, jako materiał dekoracyjny w naszym kraju wykorzystywane sa, bardzo podobne do morawickich, włoskie wapienie Botticino eksploatowane w Alpach lombardzkich, które stanowią wzorzec jakościowy dla podobnie wykorzystywanych wapieni jurajskich z całego świata (Primavori 1999).

Perspektywy rozwoju eksploatacji w skali krajowej mają zarówno duże, bloczne złoża skał powszechnie występujących, jak i mniejsze złoża skał o wysokich walorach dekoracyjnych, często z dużymi tradycjami w zakresie ich stosowania w budownictwie. Do tych ostatnich zaliczyć można złoża wapieni dewońskich, zróżnicowanych w zakresie barwy i rysunku. Ich produkcja powinna być dostosowana do potrzeb rynku poprzez zapewnienie podaży pożądanego asortymentu produktów, pochodzącego z różnych złóż. Częściowo mogłyby to być złoża czynne okresowo, lecz przygotowane do wydobycia bloków przy użyciu łatwego do transportu sprzętu, w zależności od zapotrzebowania. W Górach Święto- 
krzyskich wśród takich złóż powinny się znaleźć Bolechowice. Nieco jaśniejsze wapienie dewońskie można wydobywać z pobliskiego, mniej blocznego, zaniechanego, złoża Szewce (Góra Okraglica). Interesujące są też marmury sąsiedniego, złoża Zawada, gdzie w dobie staszicowskiej wydobywano bloki marmurowe. Atrakcyjne, czarne, bloczne dolomity, silnie użylone kalcytem występują w złożach Grocholice i Wymysłów II, zaś szare i beżowoszare wapienie o interesującym użyleniu kalcytem zabarwionym na czerwono są notowane w złożu Łagów-Piotrów (Olkowicz-Paprocka 1973).

W obszarze monokliny śląsko-krakowskiej rozwiązania wymaga odsłonięcie marmurów dębnickich spod silnie skrasowiałych wapieni gruzłowych, stanowiących niebloczny fragment profilu serii złożowej (Bromowicz 2001). Ich wydobycie z racji tradycji oraz konieczności prowadzenia prac renowacyjnych jest wskazane, tym bardziej, że oceniona ich bloczność przekracza 30\%. Możliwe jest też podjęcie eksploatacji bloków ze złoża $P a$ czóttowice, zawierającego bardzo interesujące kolorystycznie, silnie zlityfikowane, przyjmujące poler wapienie karbońskie. Nastawiona głównie na wydobycie bloków eksploatacja nie będzie zaburzać harmonii przyrodniczej okolicy.

$\mathrm{Na}$ uwagę zasługują również złoża wapieni oolitowych, których wydobycia w formie bloków zaniechano we wspomnianym złożu Gołuchów, a które jako kruszywo są pozyskiwane w złożu Gluchowiec. Tego rodzaju wapienie o interesującej barwie i teksturze znane są na rynku kamieniarskim Europy. Eksploatuje się je w różnych rejonach Francji, m.in. w Burgundii (pod nazwami: Buxy, Massangis, Ravieres) i w Normandii (Caen). Trzeba rozpatrzyć możliwości wydobycia materiału blocznego z zalegających połogo grubych ławic tych wapieni w złożu Gtuchowiec II, rozpoznanym do głębokości $70 \mathrm{~m}$ na obszarze prawie 27 ha.

Istnieją duże możliwości zaopatrzenia rynku w wapienie lekkie. Podobne są i dla piaskowców platformowych, a szczególnie można je łączyć z triasowymi piaskowcami wąchockimi oraz jurajskimi serii ostrowieckiej i drzewickiej (rys. 3). Czerwone piaskowce wąchockie budują bloczne złoże Kopulak o zasobach przekraczających $1 \mathrm{mln} \mathrm{Mg}$. W serii ostrowieckiej wydobycie znacznej ilości bloków piaskowców barwy jasnożółtej można wiązać ze złożami Żarnów i Broniów, a białych piaskowców z serii drzewickiej ze złożem Śmitów.

Piaskowce karpackie jako materiał dekoracyjny i konstrukcyjny mogą być produkowane w dużych ilościach na skalę krajową ze złóż Gtębiec i Tokarzówka (piaskowce godulskie), Sobolów (piaskowce istebniańskie), Tenczyn-Lubień (piaskowce magurskie) i Górka-Mucharz (piaskowce krośnieńskie).

Znaczenie lokalne w zakresie produkcji materiałów dekoracyjnych i architektonicznych mają niewielkie złoża o małej bloczności i niskich walorach dekoracyjnych kopaliny. Szczególnie dużo jest ich wśród piaskowców platformowych. Często wykazują znaczną zmienność w zakresie barwy, co umożliwia tworzenie różnych kompozycji. Do tej grupy należy także zaliczyć drobne wyrobiska jurajskich wapieni płytowych, produkujące tupankę, wykorzystywaną w małej architekturze.

Bardzo istotna przy rozważaniu perspektyw produkcji omawianych materiałów blocznych jest promocja konieczna dla zapewnienia odpowiedniego poziomu popytu. Tego typu 
18

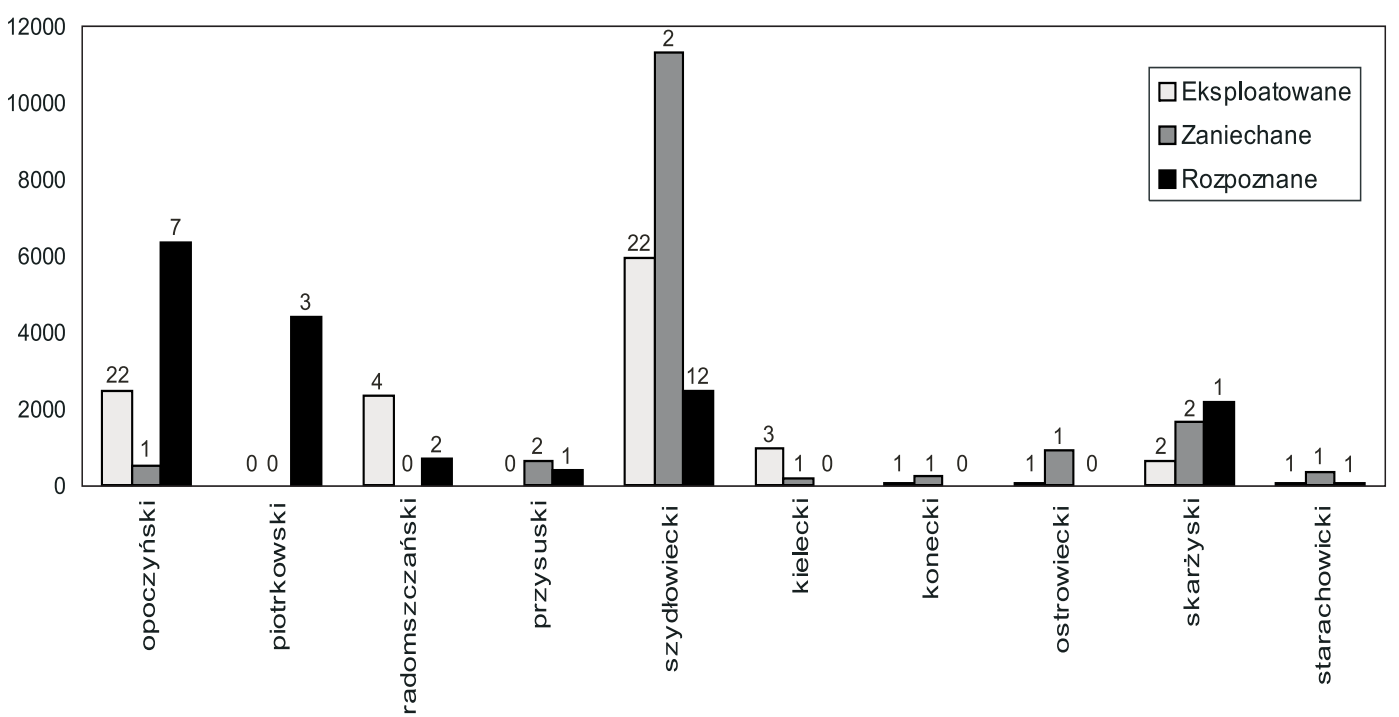

Rys. 3. Eksploatowane, zaniechane i rozpoznane złoża piaskowców platformowych w powiatach SE Polski: ich zasoby [tys. Mg] i liczba (numery na wykresie)

Fig. 3. Exploited, closed and documented deposits of continental and shelf sandstones in districts of SE Poland: their resources [thousands of $\mathrm{Mg}$ ] and number (numbers on the figure)

działaniom towarzyszyć powinna prezentacja wyrobów z promowanego kamienia i stworzenie, zwłaszcza poprzez architektów, zwyczaju jego stosowania. W tym celu należy zainteresować nim regiony, które nie posiadają tego rodzaju skał np. kraje skandynawskie. Należy też pamiętać o możliwości poprawy właściwości skał poprzez wzmacnianie ich różnymi środkami chemicznymi (Smoleńska, Rembiś 2003).

\section{Podsumowanie i wnioski}

W południowo-wschodniej Polsce zasoby wybranych złóż kamieni dekoracyjnych i architektonicznych (eksploatowanych, zaniechanych i rozpoznanych) wynoszą prawie 1,7 mld Mg, co stanowi około 41\% zasobów kamieni łamanych i blocznych tej części kraju (Bilans... 2010). Jeśli wyłączyć z nich zasoby złóż (ok. 0,4 mld Mg), w których jest lub było (złoża zaniechane) pozyskiwane kruszywo z użyciem materiałów wybuchowych, powodującym zmniejszenie możliwości uzysku bloków, to udział ten spada do $31 \%$. Przy zachowaniu obserwowanej tendencji do produkcji kruszywa ze wszystkich nadających się do tego skał udział zasobów kamieni dekoracyjnych i architektonicznych wyniesie zaledwie $6 \%$.

Dokonany przegląd złóż kamieni dekoracyjnych i architektonicznych oraz porównanie ich z pojawiającymi się na rynku kamieniarskim materiałami, pozwala na ocenę perspektyw rozwoju tej gałęzi gospodarki. Duże perspektywy na skalę europejską wiązać można 
z wystąpieniami permskich zlepieńców zygmuntowskich, triasowych dolomitów diploporowych oraz jurajskich wapieni morawickich i zalesiackich. Perspektywy rozwoju na skalę krajową mają odpowiednio zagospodarowane złoża marmurów kieleckich i krakowskich, a także wybrane, duże, bloczne złoża piaskowców z obrzeżenia Gór Świętokrzyskich i Karpat. Można przypuszczać, że dobrze przyjęte na rynku powinny być wyroby kamieniarskie z jurajskich wapieni oolitowych. Rozwój na skalę lokalną mają zapewnione złoża piaskowców z obrzeżenia Gór Świetokrzyskich i z Karpat o niewielkiej produkcji oraz wapienie jurajskie na Jurze Krakowsko-Częstochowskiej.

Niezbędne jest wyróżnienie w grupie kamieni łamanych i blocznych złóż przeznaczonych wyłącznie dla pozyskiwania materiałów dekoracyjnych i architektonicznych oraz objęcie ich ochroną przed innym wykorzystaniem. Przynależność do wspólnej grupy sprzyja zamiennemu traktowania ich kopalin jako bloczne i łamane, co w przypadku produkcji kruszywa, przy zastosowaniu technik strzelniczych eksploatacji, eliminuje materiał bloczny. Trzeba też pamiętać, że zasoby tych złóż, wobec małego w porównaniu do kruszywa wydobycia, mogą być niewielkie.

Powrót do zarzuconych kamieniarskich tradycji wymaga sporych inwestycji koniecznych dla nowoczesnego zagospodarowania złóż, a także związanych z promocją kamieni jako pięknych, naturalnych, zdrowych i tajemniczych materiałów budowlanych, które dobrze wpływają na ludzką kondycję, czego dowodem jest ciagłe ich stosowanie mimo istnienia tańszych, łatwiejszych w obróbce i bardziej odpornych tworzyw.

Istotna jest też popularyzacja wiedzy na temat zasad eksploatacji i obróbki materiałów blocznych, w bardzo niewielkim stopniu zaburzających równowage środowiska. Ma to szczególne znaczenie przy negocjacjach towarzyszących uzyskaniu zgody organów samorządowych na eksploatację kojarzoną zwykle ze znaczną uciążliwością. Dobrze przygotowany, wraz z lokalnym samorządem, program działań zmierzających do odnowy regionalnych tradycji przy równocześnie bardzo niewielkim wpływie na środowisko, powinien zainteresować zarządzające finansami odpowiednie instytucje Unii Europejskiej.

Praca finansowana w ramach projektu „Strategie i Scenariusze Technologiczne Zagospodarowania i Wykorzystania Złóż Surowców Skalnych” współfinansowanego ze środków Europejskiego Funduszu Rozwoju Regionalnego w ramach Programu Operacyjnego Innowacyjna Gospodarka 2007-2013 (um. z AGH 72.72.100.8418/C/P-67) i działalności statutowej nr 11.11.140.562

\section{LITERATURA}

Bilans... 2010 - Bilans Zasobów Kopalin i Wód Podziemnych w Polsce według stanu na dn. 31.12.2009. PIG, Warszawa.

B ro mowicz J., 2001 - Ocena możliwości wykorzystania skał okolicy Krakowa dla rekonstrukcji kamiennych elementów architektonicznych. Gospodarka Surowcami Mineralnymi t. 17, z. 1, s. 5-73.

Bromowicz J., Figarska-W archoł B., 2011a - Kamienie dekoracyjne i architektoniczne czynnych złóż Polski południowo-wschodniej. Prace Naukowe Instytutu Górnictwa Politechniki Wrocławskiej 132, s. 35-51. 
Bromowicz J., Figarska-Warchoł B., 2011b - Konieczność ochrony złóż unikalnych wapieni dekoracyjnych w Polsce. Górnictwo Odkrywkowe 1-2, s. 46-53.

Dobrowolski T., 1964 - Sztuka Krakowa. Wyd. 3, Wydawnictwo Literackie, Kraków, s. 616.

Guldon Z., Kowalski W., 1984 - W kwestii identyfikacji surowców skalnych użytych w XIV-XVIII w. do wyrobu tablic inskrypcyjnych na terenie kielecczyzny. Kwartalnik Historii Kultury Materialnej, Rok XXXII, 4, s. 525-534.

Kamieński i in. 1976 - Kamieński M., Peszat C., Rutkowski J., Skoczylas-Ciszewska K., 1968 - O wykształceniu i własnościach technicznych piaskowców godulskich. Zeszyty Naukowe AGH, Geologia, z. 12, s. 86.

Kobyle c K., 2008 - Dolnojurajskie piaskowce z okolic Przysuchy-Opoczna, ich wykształcenie i możliwości wykorzystania. Gospodarka Surowcami Mineralnymi t. 24, z. 2/1, s. 59-72.

Kostecka A., 1966 - Litologia i sedymentacja cechsztynu synkliny gałęzicko-bolechowickiej (Góry Świętokrzyskie). Prace Geologiczne Komisji Nauk Geologicznych PAN Oddział w Krakowie, 38, s. 84.

Krystek M., 2005 - Charakterystyka, eksploatacja i zastosowanie piaskowców z Góry Chełmo. Przegląd Geologiczny 9, s. 791.

Le chowicz Z., 2010 - Problematyka przynależności historycznej ziemi radomskiej. Korelaty archeologiczne. [W:] Radom. Korzenie miasta i regionu. Tom 1. Badania 2009. Instytut Archeologii i Etnologii PAN. Warszawa, s. 31-53.

Łopaciński H., 1902 - Wiadomości o marmurach w Polsce z rękopisów oraz dzieł dawnych i nowszych. Sprawozdania komisyi do badania Historyi Sztuki w Polsce 7, s. 582-595.

Łyczewska J., 1975 - Zarys budowy geologicznej Pasma Wójczo-Pińczowskiego. Biuletyn IG, 283 s. $152-188$.

Moroz-Kopczyńska M., 1977 - Litologia piaskowców krośnieńskich w obszarze między Istebną i Myślenicami w świetle ich wykorzystania w przemyśle materiałów budowlanych. Prace Geologiczne Komisji Nauk Geologicznych PAN Oddział w Krakowie, 104, s. 65.

Musiał T., 1987 - Litologia i właściwości surowcowe wapieni miocenu Roztocza. Wydawnictwa UW, Warszawa, s. 186.

Myszkowska J., 1992 - Litofacje i sedymentacja dolomitów diploporowych (środkowy wapień muszlowy) wschodniej części obszaru śląsko-krakowskiego. Annales Societatis Geologorum Poloniae 62, s. $19-62$.

Olkowicz-Paprocka I., 1973 - Możliwości uzyskania marmurów dewońskich w Górach Świętokrzyskich. Przegląd Geologiczny 1, s 20-23.

Peszat C., 1964 - Litologia jurajskich skał węglanowych między Tokarnią a Chmielnikiem. Acta Geologica Polonica 14, s. 1-78.

Pe s zat C., 1973 - Własności techniczne piaskowców Gór Świętokrzyskich. Zeszyty Naukowe AGH, Geologia t. 18 , s. 59.

Pe s zat C., 1980 - Własności fizyczno-mechaniczne skał węglanowych dewonu Gór Świętokrzyskich. Biuletyn IG 324, s. 283-319.

Peszat i in. 1976 - Peszat C., red., Bromowicz J., Gucik S., Magiera J., Moroz-Kopczyńska M., Nowak T.W., 1976 - Piaskowce karpackie, ich znaczenie surowcowe i perspektywy wykorzystania. Zeszyty Naukowe AGH, Geologia t. 2, z.2, s. 93.

Primavori P., 1999 - Planet stone. Giorgio Zusi Editore, Verona, s. 326

Rubinowski i in. 1986 - Rubinowski Z., Wróblewski T., Gągol J., red., 1986 - Atlas geologiczno-surowcowy Gór Świętokrzyskich 1:50000 z sozologiczną kwalifikacją kopalin. Tekst objaśniający Wydawnictwo Geologiczne IG, Warszawa, s. 141.

S moleńs k a A., 1983 - Zagadnienia struktur i genezy wapieni z Zalesiaków. Zeszyty Naukowe AGH Geologia, t. 9, z. 3 s. $85-98$.

Smoleńska A., Rembiś M., 2003 - Podatność wybranych piaskowców na ich strukturalne wzmacnianie. Gospodarka Surowcami Mineralnymi t. 19, z. 3, s. 5-22.

Tatarkiewicz W., 1952 - Czarny marmur w Krakowie. PAU Prace Komisji Historii Sztuki, t. X, s. 79-152.

Tołk a nowicz E., 2002 - Marmury regionu śląsko-krakowsko-częstochowskiego. Świat Kamienia 1, s. 8-10. 
Urban J., Gągol J., 1994 - Kamieniołomy piaskowców w dawnych ośrodkach górnictwa kamiennego północnej części regionu Świętokrzyskiego jako zabytki techniki i przyrody. Przegląd Geologiczny 3, s. $193-200$.

W ard zy ńs s i M., 2004 - Piękno w kamieniu zaklęte. Spotkanie z zabytkami 2, s. 6-10.

W e b e r-K o zi ń sk a E., 1961 - Górnictwo kamienne [W:] J. Pazdur (red.) Zarys dziejów górnictwa na ziemiach polskich t. II, Katowice, s. 275.

Wierzbowski A., 1978 - Ammonites and Stratigraphy of the Upper Oxfordian of the Wielun Upland. Central Poland. Acta Geologica Polonica 28/3, s. 299-333.

Zbroja i in. 1998 - Zbroja S., Kuleta M., Migaszewski Z.M., 1998 - Nowe dane o zlepieńcach z kamieniołomu „Zygmuntówka” w Górach Świętokrzyskich. Biuletyn PIG 379 s. 41-59.

KAMIENIE DEKORACYJNE I ARCHITEKTONICZNE POLUDNIOWO-WSCHODNIEJ POLSKI ZLOŻA, ZASOBY I PERSPEKTYWY EKSPLOATACJI

Słowa kluczowe

Złoża skał budowlanych, bloczność, dekoracyjność, perspektywy eksploatacji

\section{Streszczenie}

Przedstawiono stan kopalń na tle tradycji wydobycia i użytkowania surowców kamiennych. Wytypowano czynne kamieniołomy, w których tradycyjnie pozyskiwane były bloki, jak też i takie, w których z racji wykształcenia serii złożowych, bloki mogą być przedmiotem eksploatacji w przyszłości. Oceniono też złoża, w których niegdyś wydobywano materiały kamienne powszechnie stosowane jako materiały dekoracyjne w krajowej architekturze, mimo że aktualnie są one nieczynne. W sumie przeanalizowano ponad 230 złóż.

Zaprezentowano, uzasadnione ekonomicznie, perspektywy rozwoju wydobycia materiałów dekoracyjnych i architektonicznych w Polsce południowo-wschodniej na tle wymagań rynku europejskiego i możliwości wynikających zarówno z ograniczeń środowiskowych, jak i zasobowych. Ustalono, że są one zróżnicowane w zależności od walorów dekoracyjnych poszczególnych skał, ich bloczności i wielkości zasobów. Wydzielono skały i złoża, które mają możliwości rozwoju wydobycia na skalę europejską, krajową i lokalną. Pierwsze to zlepieńce zygmuntowskie, wapienie morawickie i zalesiackie oraz dolomity diploporowe. Zakres krajowy mogą mieć odpowiednio zagospodarowane złoża paleozoicznych wapieni okolic Kielc i Krzeszowic oraz niektóre bloczne złoża piaskowców z obrzeżenia Gór Świętokrzyskich i Karpat. Rozwój na skalę lokalną mają zapewnione drobne złoża piaskowców w obrzeżeniu Gór Świętokrzyskich i z Karpat oraz wapieni na Jurze Krakowsko-Częstochowskiej, produkujące materiał wykorzystywany w małej architekturze.

Wykazano zagrożenie dla złóż skał blocznych, związane ze stosowaniem materiałów wybuchowych przy wykorzystaniu ich zasobów do produkcji kruszyw łamanych. Dla złóż najbardziej atrakcyjnych skał uzasadniono konieczność ich ochrony przed eksploatacją w innych celach niż produkcja bloków. Stwierdzono, że powrót do zarzuconych kamieniarskich tradycji jest możliwy i konieczny z racji licznych powiązań, poprzez historię, architekturę i sztukę, z kulturą narodową. Wymaga on sporych inwestycji dla unowocześnienia sposobu zagospodarowania złóż, a także związanych z promocją polskich kamieni na rynku europejskim. Należy przy tym uwzględnić możliwość zaangażowania funduszy Unii Europejskiej.

DECORATIVE AND ARCHITECTURAL STONES IN SOUTH-EASTERN POLAND THE DEPOSITS, THEIR RESOURCES AND PERSPECTIVES OF EXPLOITATION

$$
\text { Key words }
$$

Building stone deposits, block divisibility, decorativeness, perspectives of exploitation 


\section{Abstract}

In the article there was described the current state of mines against a background of tradition of exploitation and application of rock raw materials. Active quarries were selected, where the extraction of rock blocks has been a tradition, as well as quarries where the geological structure of the deposit allows to exploit the blocks in the future. There were also assessed old quarries and their deposits where the popular stones had been extracted in the past and then used in domestic architecture as a decorative materials. That is a group of more than 230 deposits in total.

It has been presented economically justified perspectives of exploitation development concerning decorative and architectural rocks in south-eastern Poland against a background of European market requirements, the state of resources and environmental limitations. It was established that they are differentiated depending on the decorative properties of the rocks, their block divisibility and quantity of resources. Taking above-mentioned into consideration the deposits have been classified to groups which have the chances of exploitation development in the European, domestic and local scale. The former are Zygmuntówka Conglomerate, Morawica Limestone, Zalesiaki Limestone and Diplopora Dolomite. The domestic scope of use can be associated with properly developed deposits of Paleozoic limestones in the vicinity of Kielce and Krzeszowice and some dimension sandstones in the margin of the Holy Cross Mountains and in the Carpathians. The small deposits of sandstones from the Holy Cross Mountains margin and from the Carpathians as well as deposits of limestones from the Kraków-Częstochowa Upland, excavating material used in so called small architecture, have guarantee of local development.

Moreover there was shown the hazard to the dimension stones deposits connected with the huge consumption of their resources for the production of crushed aggregates. This problem concerns especially raw materials with good physico-mechanical properties. For the most attractive rocks it was justified the need of their protection against exploitation for the other purposes than block production. It was stated that the return to local masonry traditions is possible and necessary because of many connections with the national culture through its history, architecture and art. It requires large investments for modernize the exploitation methods as well as for promotion of Polish stones in the European market. It must be also taken into consideration the possibility of financial support from the European Union funds. 